\title{
Dil Bilgisi Öğretirken Neden Sözlüklere Başvurmalıyız?
}

\author{
Why Employ Dictionaries When Teaching Grammar?
}

\author{
Sami BASKIN*
}

ÖZ

Dil bilgisi, insanların kendilerini doğru ifade etmelerine ve başkalarını anlamalarına yardım eden bir bilgi türüdür. Ev ortamında veya diğer farkl sosyal platformlarda iletişim becerileri edinenlerin okuma, yazma, dinleme ve konuşma yetenekleri okullarda geliştirilirken bu bilgi türünden yararlanılır. Öğrencilerin düzeyleri arttıkça dil becerileri artar ve farklı dil bilgisel bilgi türlerinin farkına varırlar. Ayrıca, okullarda gerçekleştirilen ĕgitim ve ögretim faaliyetleri ögrencileri dil bilgisi hakkında araştırma yapmaya zorlar. Bunun sonucunda öğrenciler dil bilgisi kitaplarına ya da sözlüklere bakmaya yönelirler. Bu çalışma, sözlük-dil bilgisi ilişkisine odaklanmaktadır. Özellikle Türkçede kullanılan zamirlerden hareketle öğrencilerin dil bilgisine ilişkin bilgi edinmek için neden sözlüklere başvurmaları gerektiğini açıklamaktadır. Bu amaçla, Türkçe Sözlük ve dil bilgisi kitaplarındaki zamirlerin sayısı karşılaştırılmıştır. Bu karşılaştırma, sözlüklerin ayrıntılı dil bilgisel kurallar içeren kitaplardan çok daha fazla bilgi içerdiğini örneklerle ortaya çıkarmış ve ögrencilerin sadece kelimenin anlamı için değil, ögrenmeye çalıştıkları dilin dil bilgisi kurallarını da görmeleri için sözlüklere başvurması gerektiğini göstermiştir.

ANAHTAR KELIMELER

Dil bilgisi ögrretimi, Sözlük, Dil bilgisel bilgi, Zamirler

\begin{abstract}
Grammar is a type of information tool that helps people comprehend others and express themselves correctly. In fact, while reading, writing, listening and speaking abilities of those who acquire communicative abilities at home environment or other social platforms are developed and improved at school; grammatical rules of the language is knowingly or unknowingly taken into consideration. As the levels of students increase, their language skills improve and they realize different grammatical information types. Moreover, teaching/training activities at schools facilitate or even compel students to make a research on grammatical information, which of course leads students to consult to grammar books or dictionaries. This paper focuses on the dictionary-grammar relation and explains why students should consults to dictionaries to learn about grammatical information especially on the basis of Turkish pronouns. To this end, the number of pronouns in Turkish Dictionary and grammar books was compared and found that dictionaries are far more superior to grammar books in terms of providing detailed grammatical content. It was concluded that students without any exception should make use of dictionaries not only to look up a word but also to learn and understand grammatical rules of the language they are trying to learn.
\end{abstract}

\section{KEYWORDS}

Grammar Teaching, Dictionary, Grammatical Information, Pronouns

Makale Gönderim Tarihi: 15/03/2018 


\section{GíRiș}

"Dil öğretiminin asıl amacı konuşma, dinleme, okuma ve yazma ile bağlantılı olarak dildeki yetkinliği geliştirmektir. Bu amacı kolaylaştırmak için ders kitapları, dil bilgisi alıştırmaları, oyunlar, canlandırmalar, çeviriler, ses kayıtları, videobantları, yaratıcı yazma ve sözlükler gibi birçok araç kullanılabilir" (Cartens, 1995:106). Sözlükler bu araçların en eski ve en yaygın olanlarındandır. Hatta modern zamana kadar yegâne dil öğretimi kaynağıdır. Modern zamanda ise bilgi teknolojilerinin gelişmesi ve eğitim anlayışının değişmesi ile sözlükler, diğer ders materyallerinin ve öğrenme ortamlarını destekleyici, özellikle kelimenin anlamı söz konusu olduğunda onları tamamlayıcı/pekiştirici bir rol üstelenmişlerdir. Ancak öğrenciler tarafından hala önemli birer başvuru kaynağı olarak görülmektedir. Hatta Baxter'ın (1980) araştırmasına göre öğrenciler, dil öğrenirken sözlükleri diğer kitaplardan daha önemli görmektedir. Öğrenciler bu kaynak yapıtlarda genellikle kelimeye ait anlamı, doğru yazımı, telaffuzu, kullanım örneklerini ve dil bilgisel bilgiyi aramaktadır. Bu bilgi türlerinden kelimeye ait anlam, doğru yazım, telaffuz ve kullanım örnekleri açık bir biçimde yazıldığından kolayca bulunur. Ancak çoğunlukla n., v., gibi kısaltmalarla yazılmış dil bilgisel kodları bulmak ve çözümlemek o kadar kolay değildir. Bu çalışmada sözlüklerle dil bilgisi ilişkisi sorgulanmış ve kullanıcıların sözlüklerde hangi dil bilgisel bilgiyi nerede bulabilecekleri gösterilmiştir. Bunun için dil bilgisinin ne olduğu ve sözlüklerde nasıl işlendiği tanımlanmış, sonra konunun somutlaştırılması için bir dil bilgisi konusu olan zamirlerin Türkçe Sözlük’teki varlığı kullanıcıların bilgisine sunulmuştur.

\section{Araştırmanın Amacı}

Günümüzde sözlük-kullanıcı ilişkisine odaklanan araştırmalar, iki temel probleme çözüm aramaktadır: kullanıcıların ihtiyacını belirleyerek doğru sözlüklerin hazırlanması ve eserlerin niteliklerini belirleyerek kullanıcıları doğru sözlüklere yönlendirmek. Bu araştırma, ikinci grup ile ilgilidir. Amaç, sözlükler ile dil bilgisi arasındaki ilişkiyi gün yüzüne çıkarmak ve öğrencilerin bir dil bilgisel bilgi için neden sözlüklere başvurması gerektiğini somut örneklerle (zamirler) göstermektedir.

\section{Araştırmanın Yöntemi}

$\mathrm{Bu}$ çalışma, bir doküman analizine dayanmaktadır. Doküman analizi, mevcut belgeleri inceleyerek veri toplamanın bir yoludur. $\mathrm{Bu}$, belgelerin bir değerlendirme konusu etrafinda fikir edinmek veya yeniden anlamlandırılmak üzere araştırmacı tarafından yorumlandığı bir nitel araştırma şeklidir. Sistematik bir değerlendirmede reklamlar, gündemler, katılım kayıtları, toplantı tutanakları, kitaplar, broşürler, günlükler, dergiler, etkinlik programları (basılı taslaklar gibi), mektuplar, bildiriler, haritalar, çizelgeler, gazeteler, başvuru formları, özetler, radyo ve televizyon programı senaryoları gibi değişik biçimlerde hazırlanmış kayıtlar (Bowen, 2009) kullanılabilir. Bu araştırmada sözlük ve dil bilgisi ile ilgili yapılan araştırmalar dikkate alınarak ilgili terimler betimlenmiş, Türkçe Sözlük’teki dil bilgisel bilgi türleri belge tarama yoluyla elde edilmiş ve sınıflandırılmış, ardından bir dil bilgisel bilgi türü olan zamirler sözlüğün içinden çekilerek listelenmiştir. Sonra elde edilen veriler yorumlanarak öğrenciler başta olmak üzere sözlük insanların dil bilgisel bir bilgi için neden sözlüklere başvurması gerektiği gösterilmiştir.

\section{Dil Bilgisi}

Eski Yunanlılar ve Eski Hintlilerden beri insanlar doğru yazıp okumak amacıyla dillerinin bağlı olduğu kuralları tespit etmeye çalışmışlardır. Bu kuralların meydana getirdiği bilgi koluna dil bilgisi denmektedir (Banguoğlu, 2007: 18). Kurallar dilin çeşitli ögelerine aittir. Zira dil karmaşık, büyük bir sistemdir ve çeşitli ögelerden oluşmaktadır. Dili oluşturan en küçük ögeler seslerdir. Seslerin genel olarak tek başına anlamı yoktur. Sesler diğer ögelerle birleşince anlam kazanırlar. Bu birleşme bazı kurallara bağlı olarak gerçekleşmektedir. Kurallara göre birleşen sesler, heceleri, kelimeleri ve cümleleri oluşturmaktadır (Güneş, 2007: 261). Yani dili meydana getiren unsurlar sirasiyla sesler, kelimeler ve sözlerdir (cümlecikler ve cümleler). Bu yüzden dilin kurallarını kaydeden ve açıklayan bir bilim alanı olan dil bilgisinin bu konuları işleyen alt alanları türemiştir. Bunlar, ses bilgisi (fonetik), yapı bilgisi (morfoloji) ve söz dizimidir (sentaks). Bunlara anlam bilgisini (semantik) eklemek de mümkündür (Banguoğlu, 2007: 20). Ses bilgisi (fonetik), dilin seslerini inceler. Onların çıkarılış özelliklerini, kelimelerdeki sıralanışlarını, yüklendikleri görevleri ve uğradıkları değişimleri inceler (Dursunoğlu, 2017: 34). Yapı bilgisi (morfoloji), bir dildeki kök ve ekleri, bunların birleşme yollarını, eklerin anlam ve görevlerini, dilin türetme ve çekim özelliklerini (Vural ve Böler, 2012: 139) inceler. Söz dizimi (sentaks), cümleyi ve kelime gruplarını (cümlecik) oluşturan kuralları, kelimelerin bir araya gelme koşullarını, kelimeler ve cümle ögeleri arasındaki ilişkiyi inceler (Özmen, 2016: 3). Anlam bilgisi ise (semantik) anlamı, anlam yapılarında ve anlam değişmelerindeki değişmez ve evrensel nitelikleri araştıran (Karaağaç, 2013: 133) bilimdir. Bütün bunlar birleştirildiğinde dil bilgisi, "bir dilin ses, 
biçim, cümle ve metin yapısını inceleyen, anlam ve görevlerini ortaya koyan geniş bir alan" (Güneş, 2013: 173) haline gelmiş olur. Şimdiye kadar yapılan çalışmaları derleyen Jean- Pierre Cuq, dil bilgisi tanımlarını dört grupta toplamıştır. Ona göre dil bilgisi;

- Bir dili doğru konuşmak için oluşturulan düzenleyici ilk ve kurallar bütünüdür.

- Bir dilin ilkelerini inceleyen eğitsel etkinlikler, doğru konuşma ve yazma sanatıdır.

- Dilin iç işlevleri üzerine geliştirilen bir teori ve aynı zamanda gözlem aracıdır.

- Dile ilişkin öğretilecek açıklayıcı, süreçsel ve koşul bilgileridir" (Cuq, 2003'ten aktaran Güneş, 2013:173).

\section{Sözlük}

Sözlükler, kelimeler hakkında güvenilir ve detaylı bilgiyi veren kaynaklardandır. Bu yüzden dil öğretiminde önemli bir yere sahiptir. Sözlükler en çok, her hangi bir kelimenin anlamına bakmak veya onun doğru telaffuzunu öğrenmek için kullanılır. İleri düzey kullanımlarda ise kelimenin eş anlamlısını veya kökenini bulmak veya farklı metinlerdeki kullanımlarını öğrenmek için tercih edilir. Bu bağlamda, dil öğrenmek isteyen ve dil öğreten bütün herkes bir sözlüğe ihtiyaç duyar (Baskın, 2014: 445). Başta öğrenciler olmak üzere hemen herkesin kullandığı bu eserler, "büyük ölçüde alfabetik düzene göre ama aynı zamanda konu türüne göre de sıralanmıș, genel olduğu kadar özel, kelimelerle ilgili tek dilli, iki dilli veya çok dilli bir başvuru kaynağıdır" (Hartmann ve James, 2002: 4). Bu tanımın odak noktası sözlüğün söz varlığı ve bu söz varlığının açıklandığı dil/dillerdir. Farklı bakış açıları sözlüğün tanımında da değişiklikler görülmesine neden olur. Örneğin Cabre'ye göre sözlük, seçilmiş kelimeleri veya diğer dilsel öğeleri bir araya getiren ve onlar hakkında bilgi veren dil bilimsel bir üründür (Cabre, 1992: 31). Türk Dil Kurumunun Güncel Türkçe Sözlük'ünde sözlük, "bir dilin bütün veya belli bir çağda kullanılmış kelime ve deyimlerini alfabe sırasına göre alarak tanımlarını yapan, açıklayan, başka dillerdeki karşılıklarını veren eser, lügat”tir (erişim tarihi: 20.10. 2016). Türk dil biliminin duayenlerinden Doğan Aksan sözlük kavramını, "bir dilin (ya da birden çok dilin) sözvarlığını, söyleyiş biçimleriyle, yazımlarıyla veren, bağımsız biçimbirimleri temel alarak bunların, başka öğelerle kurdukları söz öğeleriyle birlikte anlamlarını, değişik kullanımlarını gösteren bir sözvarlığı kitabı..." (Aksan, 1996: 77) olarak tanımlamıştır. Akalın'a göre sözlük, "bir dilin bütün veya belli bir dönemindeki sözcüklerini yazılışları, türleri, söylenişleri, temel ve yan anlamları, kullanış özellikleri bakımından açıklayan, edebi metinlerden seçilen cümlelerle örneklendiren, alıntı sözcüklerin hangi dilden geçtiğini bildiren başvuru kaynağıdır (Akalın, 2010: 268). Eminoğlu'na göre ise sözlük, "dillerin söz varlığını içine alma, dilin yapısı ve işleyişi hakkında bilgi verme, toplumun eğitim ve bilgi düzeyinin sonuçlarını ortaya koyma, diğer dil ve toplumlarla kurulmuş ilişkileri gösterme gibi pek çok konuda, ulusların kültürü içinde önemli bir yere sahip bilgileri içermesi bakımından, bilimsel araştırmaların temelini oluşturan kaynaklardandır" (Eminoğlu, 2010: 3). $\mathrm{Bu}$ tanımları daha da arttırmak mümkündür. Örneğin Bergenholtz'a göre sözlük, "belirli ihtiyaçları/gereksinimleri karşılayan ve en az iki maddeden oluşan bilgi aracıdır. İletişimsel ve bilişsel temel işlevleri gerçekleştirmeyi amaçlayan tüm sözlük bilimsel kaynak yapıtlara verilen genel bir isimdir, çatı terimdir. Kullanıcının metin alımı, üretimi ya da çeviri konusunda ihtiyaç duyduğu anda ya da bir sözcügün bileşenleri hakkında daha fazla bilgi edinmek istediğinde başvurabileceği ve belirli bir konu ya da dil öğeleri ve birçok dış metin/bölümle ilgili sözlük maddeleri içeren kaynak yapıttır" (Bergenholtz, 2012: 25-30). Jackson'a göre (2002: 1) sözlük, bir dilin kelime deposudur.

Sözlükler ilkel (prototip) sözlükler ve güncel sözlükler olarak sınıflandırabilir. İlkel (prototip) sözlükler tek dilli, genel amaçlı, alfabetik sözlüklerdir. Sözcükler/maddeler tek dilde tanımlanır ve sözcükle ilgili verilen bilgilerin yapısı ansiklopedik değil daha çok dil bilimseldir. Güncel sözlükler ise genel olarak yazım, telaffuz, heceleme, sözcük türü, etimoloji, sözlüksel anlam, kullanım durumu, eş dizim, sınıflandırma, dil dış1 ya da ansiklopedik bilgiler gibi sözlüksel verilerle ilgili bilgi sağlayan sözlüklerdir (Sterkenburg, 2003: 3-8). Bu yüzden güncel sözlükler ile dil bilgisinin yolu çok sık biçimde kesişir.

\section{Sözlüklerle Dil Bilgi İlişsisi}

Bir dil, sözlük ve dil bilgisinden oluşur. Bir bakıma, sözlük, dil topluluğunun dünü; dil bilgisi ise bugünü ve yarınıdır (Karaağaç, 2013: 289). Sözlük ve dil bilgisi arasındaki bu ilişkiyi Jackson (1985: 53), "Dil bilgisi ve sözlük, dili tanımlamamızı sağlayan tamamlayıcı yapılardır." biçiminde açıklamıștır. Aralarındaki bu tamamlayıcı ilişkiye rağmen bunlar yan yana yani bitişik bir ilişki yaşamazlar. Hakikatte "sözlük isim, geçişli fiil gibi birtakım dil bilgisi terimlerini kullanmak durumunda olduğundan açık veya örtük biçimde dil bilgisine dayalıdır (Jackson, 1985: 53). Sözlükteki dil bilgisel bilgiler sadece isim, fiil gibi terimlerle sınırlı değildir. Jackson (1985: 54), sözlükte dört çeşit dil bilgisel bilgi bulunduğu belirtmiştir. Ona göre bu bilgiler şöyledir: 
- İlk olarak özellikle genel dil bilgisine ait ifadelerden anlaşılmayan sözlüksel ögelerin aldığı eklere iliş̧kin bilgi içerir.

- İkinci olarak her sözlüksel öge genellikle isim, sıfat gibi ait olduğu sözcük türü ile gösterilir.

- Üçüncü olarak sözlük girdisinin daha ayrıntılı söz dizimsel yapısı belirtilebilir. Örneğin, fiiller geçişli veya geçişsiz olarak gösterilir.

- Dördüncü olarak dil bilgisel, özellikle de söz dizimsel bilgi sözlük girdilerinde yer alan örnek tümceler kullanılarak gösterilebilir.

Sözlüklerin dil bilgisel bilgi içerdiğini belirten pek çok çalışma bulunmaktadır. Örneğin Dash (2007: 228), sözlükleri "sözlüksel birimlerle ilgili yazım/yazımsallık, dil bilgisi, etimoloji, anlam, kullanım vb. dil bilimsel bilgiler veren" kaynaklar olarak görmektedir. Kocaman'a (1998: 111) göre özellikle son yıllarda hazırlanan sözlükler, anlam açıklamaları yanında kullanım bilgileri ve dil bilgisi özetleri vermektedir. Abecassis (2007: 256), sözlüklerin "anlam, etimoloji, dil bilgisi, birlikte kullanım gibi konularda mümkün oldukça çok bilgi ile donatılarak fonksiyonlarının arttırılabileceğini, bu yüzden yer sınırlaması taşımayan elektronik sözlüklerin basılı sözlüklerden daha avantajlı olduğunu belirtmiştir. Yine Dakum'a (2001: 27) göre sözlükler kelime türetimi, anlam, heceleme ve telaffuz hakkında bilgi verirler. İyi bir sözlük dil bilgisi ve kullanım, eşanlam ve türetimin yanında sözlü ve yazılı İngilizce hakkında bilgi verir. Görüldüğü gibi bu açıklamaların hepsinde sözlüklerin dil bilgisel bilgi içerdiği belirtilmiştir. Ama sözlüklerdeki dil bilgisinin asıl önemine atıfta bulunan kişi Sterkenburg'tir. Sterkenburg'e (2003: 3-8) göre, bir kaynağın sözlük olarak adlandırılabilmesi için bazı nitelikleri (kriter) taşıması gerekir: formal nitelikler ve işlevsel nitelikler. Formal nitelikler, sözlüklerdeki dil bilgisel bilgilerdir. Sözlükler, dilin kuralları yani dil bilgisi üzerine inşa edilirler. Kullanıcılar sözlüğün her yerinde bu bilgilerle karşılaşırlar. Hangi bilgi türünün sözlüğün neresinde yer aldığını bilmek için sözlüğün yapısını bilmek gerekir. Sözlük (burada basılı sözlük kasedilmiştir), bir kitaptır. Başı, ortası ve sonu vardır. Ancak baş kısmında, ortasında ve sonunda farklı farklı bilgilere ve düzenlemelere sahiptir. Bu yüzden kullanmadan önce sözlüğün yapısını, nasıl bir kitap olduğunu bilmek gerekir. Sözlük yapısını bazı bilim insanları (Nielsen, 1990; Bejoint, 2000; Landau 2001 cv.) bütüncül yapı (macrostructure) ve parçacıl yapı (microstructure) olmak üzere ikiye ayırmıştır. Bazı bilim insanları bunu (Hartmann ve James 1998; Svensen, 2009 vb.) bütün yapı (megastructure), bütüncül yapı ve parçacıl yapı olmak üzere üçe ayırmıştır. Bazıları (Bergenholtz and Tarp, 1995 vb.) da ilişkisel yapıyı (mediostructure) eklemiş ve sözlüğün en az dört bileşeni olduğunu varsaymışlardır. Bugün sözlüklerin çeşit çeşit olması bu yapılardaki farklılıklardan gelmektedir. Dil bilgisi ise bu yapıların ve doğal olarak sözlüklerin şekillendiricisidir. Bu durumu somutlaştırmak ve dil bilgisel bilginin sözlükteki yerini göstermek için Türkçe Sözlük'ten örnekler sunulmuştur.

Türkçe Sözlük'ün ön kısmında yer alan dil bilgisel bilgiler: Türkçe Sözlük'ün yıllar içindeki gelişiminin anlatıldığı bu bölümde sözlük içeriğinin dağılımı anlatılmıştır. Örneğin on birinci baskı için "sözlükte 77.005 madde baş1, 15.287 madde içi olmak üzere toplam 92.292 söz bulunmaktadır. Bu sözlerin 53.451'i isim, 12.666's1 sıfat, 3,3312'si zarf, 88'i zamir, 40'1 edat, 299'u ünlem, 50'si bağlaç, 9,9112'si ise fiildir' (Türkçe Sözlük, 2011: XXI) bilgisi verilmiştir. Bu bilgi sözlüğün söz varlığının bir dil bilgisel bilgi çeşidi olan kelime türüne göre dağılımını ifade etmektedir. Kullanıcılar, Türkçenin söz varlığında hangi tür kelimeden (isim, fiil, sıfat vb.) kaçar tane olduğunu sözlüğün ilk kısmındaki bu bilgiden öğrenebilirler ve sözlüğü baştanbaşa tarama zahmetinden kurtulurlar. Kullanıcılar yine bu bölümde Madde Düzeni başlı̆ğ altında verilen bilgilere bakarak ileride karşılaşacakları dil bilgisel bilgilerin nasıl kodlandığını öğrenebilirler. Örneğin "madde başında her sözün dil bilgisindeki yeri ve fiillerden önce gelen nesnelerin hangi tür eklerle kullanıldığı kısaltmalarla gösterilmiştir: a., sf., e., zf., (-e), (-den), (nsz) vb.” (Türkçe Sözlük, 2011: XXIII) bilgisi dil bilgisel bilgilerin kısaltmalarla gösterileceğini ve bu kısaltmaların ilgili tablodan bakılarak öğrenilmesi gerektiğini vurgular. Böylece kullanıcı dil bilgisel kısaltmaları öğrenmeye yönlendirilmiş olur. Yine Yazım ve Söyleyiş başlığı altında Türkçedeki kelimelerin ek aldıklarında uğrayacakları değişim anlatılmış ve ünlü düşmesi, ünsüz yumuşaması gibi dil bilgisi konuları anlatılmıştır (Türkçe Sözlük, 2011: XXV-XXVI).

Türkçe Sözlü̈k’ün arka kısmında yer alan dil bilgisel bilgiler: Sözlüğün arka kısm1, yani alfabetik düzenlenmiş söz varlığının bitiminden sonraki kısım, doğrudan dil bilgisi konularının anlatıldığı bölümler içermektedir. Bu yüzden sözlüğün bu kısımı yer yer bir dil bilgisi kitabını andırır. Örneğin Türkçenin Ses ve Yapı Özellikleri, Genel Yazım Kuralları, Yapım ve Çekim Ekleri başlıkları doğrudan dil bilgisi konularına aittir. Hatta kullanıcılar, hiçbir dil bilgisi kitabında tam listesini bulamadıkları ekleri sözlügün bu kısmında bulabilirler. Onlar, Yapım ve Çekim Ekleri başlığı altındaki listeye bakarak Türkçenin ek konusundaki zenginliğini öğrenebilirler.

Türkçe Sözlük'ün orta kısmında yer alan dil bilgisel bilgiler: Orta kısım, aslında sözlük kullanıcılarının bilgiyi aradığı asıl yerdir ve sözlük dendiğinde akla ilk gelen kısımdır. Kullanıcılar, merak ettiklerini doğrudan bu bölüme yönelerek bulmaya çalışırlar. Ancak bu bölüm diğerleri gibi düzenlenmemiştir ve doğrudan bir 
başlık ile bu başlığı tamamlayan açıklamalar biçiminde değildir. Burada dil bilgisel bilgi çoğu zaman kısaltmalarla şifrelenmiştir. Bu bilgilerden yararlanmak için sözlüğün nasıl düzenlendiğini bilmek gerekir. Bu kısımda sözlük hem yatay biçimde hem de dikey biçimde çeşitli düzenlemeler içir. Sözlüğün yatay biçiminde yazım, telaffuz, çekim ekleri, kelime sınıfları, tanımlar, örnekler, kullanım, alıştırmalar, köken bilgisi (Jackson, 2002: 26) gibi ögeler yer alır ki bunlar sözlük kullanıcısının madde başı ile ilgili aradığı bilgilerdir. Bu bilgilerin düzenine ve içeriğine sözlüğün parçacıl yapısı (microstructure) denmektedir. Parçacıl yapıda verilen bilgi türlerini Svensen (2009: 5) şöyle sınıflandırmıştır:

1. Yazım, telaffuz ve biçim bilimsel (çekimler ve sözcük türetme) özellikler (söylem/anlatıma ilişkin özellikler);

2. Anlamın açıklanmasını sağlayan anlam bilimsel özellikler (içeriğe ilişkin özellikler);

3. Diğer sözcük ve birleşik sözcüklerle birleşim şekilleri gibi söz dizimsel özellikler (syntagmatic işlev);

4. Kullanıma ilişkin edim bilimsel (pragmatik) özellikler.

Aslında Svensen'in sunduğu bu başlıkların ilk üçü doğrudan dil bilgisi ile ilişkidir. Bu da dil bilgisinin sözlük yazımında ne kadar etkili bir faktör olduğunu açıkça göstermektedir. Kullanıcılar, Svensen'in belirttiği dil bilgisel bilgileri Türkçe Sözlük'ün parçacıl yapısında (microstructure) çok rahat bir şekilde bulabilirler. Örneğin sözlüğü kullanan hemen herkes n. (isim) veya v. (fiil) gibi kısaltılmış girdileri hatırlayacaktır. Bunlar sırasıyla isim ve fiilin yerini tutmaktadır. Fakat sözlükte bulunan dil bilgisel bilgi genellikle çok daha fazladır ve aynı madde içinde birden fazla dil bilgisel işaretleme bulunabilir. Kullanıcıların Türkçe Sözlük'ün parçacıl yapısında (microstructure) bulabilecekleri dil bilgisel bilgilerden bazıları şunlardır:

Fiillerin aldığg zaman ekleri, -er (geniş zaman eki) vb.

Fiilin nesne alıp almaması, $n s z$ (geçişsiz fiil, nesne almayan fiil) vb.

Fiilden önceki nesnenin aldığı durum eki, - $e$ (e durum ekiyle kullanılan fiil) vb.

Madde başı ile ilgili birleşik fiil, adım (veya adımını) atmak vb.

Kelime türü, băg. (bağlaç) vb.

Madde başı olan kelimenin ünlü ile başlayan bir ek aldığında söyleniş biçimi, ahbap $+l>a h b a b l$ vb.

İkinci hecedeki dar ünlünün düşmesi durumu, burun $+u>b u r n u$ vb.

Ünlüyle başlayan ekle veya yardımcı fiille kullanımı, zan $+\imath>$ zannı, zan+etmek $>$ zannetmek $\mathrm{vb}$.

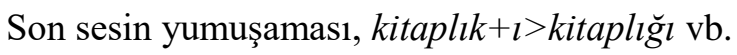

İnce sıradan ek alma gerekliliği, santral $+i>$ santrali vb.

Eş seslilik durumu, çırçır (I), çırçır (II), çırçır (III) vb.

Sözlükteki dil bilgisel bilgiler sadece parçacıl yapıda bulunmaz. Kullanıcılar bazen herhangi bir kelimenin değil doğrudan dil bilgisel terimlerin açılamalarına ihtiyaç duyarlar. Örneğin herhangi bir zamiri, sıfatı, ismi sözlükten araştırmak isterler. Onların bu ihtiyacını sözlükte madde başı olarak yazılmış olan dil bilgisel yapılar karşılar. Bu dil birimleri diğer söz varlığı unsurları ile uyumlu bir düzen içerisinde sözlük içinde saklanmıştır. $\mathrm{Bu}$, sözlüğün bütüncül yapısıdır. Bütüncül yapı, aynı zamanda bir sözlük içinde madde başı olarak kendisine yer verilen sözlük birimlerin sıralanma biçimidir. Bunu iki biçimde yapmak mümkündür. Birincisi ve yaygın olanı alfabe düzenidir. Buna alfabetik yaklaşım da denir. Diğer taraftan kelimelerin aralarındaki anlam ilişkilerini dikkate alarak bir sıralama yapmak mümkündür. Buna da anlam bilimsel (semantik) yaklaşım denir. İster alfabetik olsun isterse anlam bilimsel bir sıralama düzenine sahip olsun sözlükler, özellikle genel sözlükler, pek çok dil bilgisel ögeyi madde başı yaparlar. Kullanıcılar da sözlük düzenine uygun hareket ederek bu dil bilgisel birimleri bulmaya, açıklamalarını ve örneklerini okumaya başlarlar. Alfabetik sırayla hazırlanmış sözlüklerde bu bilgiler alfabe sıraları geldikçe yazıldığından dağınıktırlar. Ancak semantik yaklaşıma göre yazılmış olan sözlüklerde bu konuları bulmak daha kolaydır. Çünkü genellikle hepsi bir arada bulunurlar. Türkçe Sözlük alfabetik düzenlenmiş bir başvuru kaynağ 1 olduğundan bütüncül yapıdaki dil bilgisel birimler dağınıktır. Bu çalışmada sözlükte dağınık halde bulunan zamirler seçilerek bir araya getirilmiştir. Bunda amaç hem sözlüklerin bütüncül yapısındaki dil bilgisel 
bilgilerin / terimlerin yer aldığını göstermek hem de başta öğrenciler olmak üzere kullanıcıların Türkçenin söz varlığındaki zengin zamir türünü bir arada görmesini sağlamaktır.

\section{Türkçe Sözlük’te Yer Alan Zamirler} oldun."

Âlem - 7. (madde içindeki anlam sırası) zamir Herkes, başkaları "Bu yaptığından dolayı âleme rezil

Aynısı - zamir Ayırt edilemeyecek kadar benzerlik göstereni, benzeri, tıpkısı (Olcaycığım sadece sarı kısmı çevir)

"Bana göstereceğin sayginın aynısını yengene göstermek zorundasın." - A. Kutlu

Bana - zamir Ben zamirinin yönelme durumu eki almış biçimi

Başka biri - zamir Diğer bir kimse

"Çoğu zaman ben, kendimi mesut edeyim derken başka birini bedbaht ediyorum." - A. M. Dranas

Başkası - zamir Diğer bir kişi, herhangi bir kimse, diğeri, ötekisi

"Sana peşin haber vereyim ki onlar kızlarının başkası ile âşıtaşlık yapmasını istemezler." - O.

C. Kaygilı

Ben (III)- 3. zamir Teklik birinci kişiyi gösteren söz

"Bütün sevgileri atıp içimden / Varlı̆̆ımı yalnız ona verdim ben" - A. K. Tecer

Benimki - 2. zamir Kadınların kocalarından, kocaların karılarından söz ederken kullandıkları söz

3. zamir Yakın çevrede olan bir kimseden söz ederken kullanılan bir söz

Beriki 2. zamir Beride olan şey veya kimse

"Fakat berikiler onu işitmemiş gibi masaya oturdular." - P. Safa

Bir başkası - zamir Başkası

"Bir başkasını gönderir, soruşturmayı daha da derinleştirirlerdi." - E. Bener

Bir diğeri - zamir Başkası

"Bugünkü zevkimize muvafik olarak tasfiye edilmiş, ayıklanmış bir rivayeti bir diğerinden seçebilmek pek güçtür." - A. H. Çelebi

Birbiri - zamir Karş111klı olarak bir diğeri

"O zaman on dört paşa büyük, hudutsuz bir hayret içinde İzzet Paşa'nın sonra da birbirlerinin yüzüne baktılar." - N. S. Örik

Birçoğu - zamir Çok sayıda olan kimse veya şey

"Yine içimizden birçoğu güzelliği kendi gözleriyle değil başkalarının gözlerine inanarak kabul etmek ister." - A. H. Çelebi

Birçokları - zamir Çok sayıda olan kimse veya şey

"Birçokları onu memleketin mukadderatına yabancı bulmuşlardır." - A. Ş. Hisar

Biri - 1. zamir Bir tanesi

"Kurşun vınlayarak gidip bahçedeki ağaçlardan birine saplanmıştı." - A. Kulin

2. Bilinmeyen bir kimse

"İhtimal, hırsız Eşref'in hayranlarından biriydi." - O. S. Orhon

Birileri - zamir Bazı kimseler

Birisi - zamir Herhangi bir kimse

"Birisi sezecek olsa kim bilir ne dedikodular çıkarılırdı." - E. Bener

Birkaçı - zamir Az sayıda olan kimse veya şey

"Şiirlerinin birkaçı erişilmez derecede güzel belki de şair olmaya özenmediği için eşsiz incilerdir." - A. Kabaklı

Birtakımı - (sayfa - 360) (1.anlam) (zamir)

zamir Bazıs1, kimi

Biz (I)- 1. zamir Çokluk birinci kişiyi gösteren söz

"Biz, Türkler, bütün tarihî hayatımızca hürriyet ve istiklale timsal olmuş bir milletiz!" - Atatürk

2. zamir Bazen teklik birinci kişi zamiri "ben" yerine kullanılan bir söz

"Biz kendisini aldığımız zaman vücudu pek ince idi." - H. R. Gürpınar 
Bizimki - 2. zamir Kadınların kocalarından, kocaların karılarından söz ederken kullandıkları söz "Sağ ol şekerim, bizimki de neredeyse gelir. Benim de hazırlık yapmam lazım." - A. Ümit

3. zamir Yakın çevremizde olan bir kimseden söz ederken kullanılan bir söz

"Artık bizimki, nişanlısı Perihan'ı ekiyor, her gün tek başına plaja geliyordu." - N. Hikmet

Böylesi - 1. zamir Bunun gibisi, bu biçimde olanı

"Padişah bakmış, babayani, hırpani bir derviş. Ne gelir ki böylesinin elinden?" - E. Şafak

Bu - 2. zamir En yakında bulunan bir varlığı veya biraz önce anılan bir şeyi işaret yolu ile belirtmek için kullanılan bir söz

"Oysa bizi bekleyen yaşam bu değildi." - R. Mağden

Buncası - zamir Bu kadarı

Bunlar - zamir Bu zamirinin çokluk biçimi

"Bunlar, matbaada basılan ve dağıtımı yapılan dergilerdi artık." - A. Kutlu

Cümle - 4. zamir Herkes

"Cümleye uzun ömürler dilerim." - B. Felek

Cümle âlem - zamir Herkes

Cümlesi - zamir Hepsi

"Cümlesi masanın başında koltuklara yerleştiler." - E. E. Talu

Çoğu - 1. zamir Bir şeyin büyük bölümü

"Biz o zaman okuduğumuz mısraların çoğunu ezber bilirdik." - A. Ş. Hisar

2. zamir Çok kimse

"Arkadaşlarımın çoğu gibi mektebe lalalarla, uşaklarla gitmedim." - A. H. Tanpınar

Çokları - zamir Birçoğu

"Çokları bunu, burnumun büyüklüğüne verir." - A. Ağaoğlu

Diğeri - zamir Ötekisi, başkası

Dost düşman - zamir (mecaz anlam) Herkes

"İmzanın arkasına saklanan adam, dost düşman her kim olursa olsun maksat hasıl olmuştu." - H. R. Gürpınar

Dünya - 5. zamir Herkes

Dünya âlem - zamir Herkes, bütün insanlar

Falan - 1. zamir Söylenmesi istenmeyen veya gerekli görülmeyen bir özel adın yerini tutan kelime, filan

"Bana "falan geldi, falan gitti" diye anlatmaya başladı."

Falanca - 2. zamir Falan kimse

Falanca geldi."

Filan - zamir Falan

Hacısı hocası - zamir (mecaz anlam) Kim varsa, herkes, hepsi

Hangi biri - zamir Çok olanlardan hangisi

"Hangi birini sayayım?"

Hangisi - zamir "Kim, hangi şey" anlamlarında kullanılan bir söz

"Bende olmayanın hangisini sonradan edinebilirim?" - A. Kutlu

Hepsi - zamir Bütünü, tamamı, tümü, cümlesi

"Mücrim onlarmış gibi, baktım, hepsi hüzünde / Çocuk utangaçlığı var hepsinin yüzünde" - F. N. Çamlıbel

Her biri - zamir Ayrı ayrı hepsi

"Şu dünyada her birimiz alnımızın teriyle ekmeğimizi çıkarmak zorundayız." - Halikarnas Balıkçısı

Herhangi biri - zamir Belli olmayan, rastgele biri

"Herhangi biri gelsin."

Herkes - zamir İnsanların bütünü, cümle âlem

"Neylersin ölüm herkesin başında / Uyudun uyanmadın olacak" - C. S. Tarancı

Hiç kimse - zamir Bir kişi bile 
Hiçbiri - zamir Bir teki, biri bile

Kaçı - zamir Ne kadarı, kaç kişi

"Bunların kaçı sana ait?" "Kaçına belge verilecek?"

Kâinat - 3. zamir Herkes

Kendi - 1. zamir İyelik ekleri alarak kişilerin öz varlığını anlatmaya yarayan dönüşlülük zamiri, zat

"Ankara Palas'ta kendisine dörtte üç oranında indirim yapılırdı." - Ç. Altan bir söz

Kim (I) - zamir "Hangi kişi?" anlamında cümlede, özne, tümleç, nesne, yüklem görevinde kullanılan

"Kim sesini çıkarırsa karşısında beni bulur." - H. Z. Uşaklıgil

Kimi - 1. zamir Birtakımı, bazıs1, kimisi

"Kimi duvarlarına renkli taşlar kaktı. Kimi bahçesine ağaç dikti." - L. Tekin

Kimisi - zamir Bazısı, birtakımı, kimi

Kimse - zamir Herhangi bir kişi, kim olduğu bilinmeyen kişi

"Kimsenin girdisi çıktısı, alacağı borcu ile uğraşmak istemiyordum." - N. Cumalı

Kimsecik - zamir Hiç kimse

"Evladım, sakın kimseciklere borç etme!" - Y. Z. Ortaç

Neresi - 1. zamir Hangi yönü, ne tarafı

"Bunun neresi güzel?"

Nesi - 1. zamir Akrabası mı, yakını mı?

"Ali, Ahmet'in nesidir?"

2. zamir Hangi yönü, hangi tarafı?

"Bunun nesi iyi?" - H. Taner

Ne (II) - 1. zamir Hangi şey

2. zamir Her şey

"Ne görse ister. Kimin nesi varsa. Ne isterse yapar."

3. zamir Birçok şey

"Neler söylüyor? İnsan aklı neler keşfediyor?"

$\mathbf{O}$ (II)- 2. zamir Teklik üçüncü kişiyi gösteren bir söz

"Ben uyandığım zaman o gitmişti." - R. H. Karay

3. zamir İki veya daha çok şeyden, daha önce sözü geçeni gösteren bir söz

O bu - zamir Bazı kimseler ve nesneler

Ol - 2. zamir O gösterme zamiri

Ona - zamir O zamirinin yönelme durumu eki almış biçimi

"Yeğeninin ona çeken tek yanı yoktur." - T. Buğra

Oncası - zamir O kadarı

Onlar (II)- zamir $\mathrm{O}$ şahıs zamirinin çokluk biçimi

Onunki - 2. zamir Üçüncü kişinin karısından veya kocasından söz ederken kullanılan söz

Öbürkü - zamir Öbürü

Öbürleri - zamir Ötekiler, öbür kişiler veya şeyler, diğerleri

"Öbürleri, elleri silahlarında bu oyunu seyrediyorlardı." - Ö. Seyfettin

Öbürü - zamir Öteki, öbür kişi veya şey, diğeri, öbürkü

Öteki - 1 zamir Diğeri, öbürü

"Bu iki perdelik bir oyun imiş, bitince ötekini oynayacaklarmış!" - M. Ş. Esendal

Öteki beriki - 1. zamir Olur olmaz kimseler

"Öteki berikine kefil olmayı bir nevi vazife telakki edermiş." - A. Ş. Hisar

Ötekileri - zamir Ötede bulunanlar, diğerleri, başkaları

Ötekisi - zamir Ötede bulunan, diğeri, başkası

"Beriki sandalye kırık, ötekisini al."

Pek çoğu - zamir Yeterinden fazlası 
Sen - 1. isim Teklik ikinci kişiyi gösteren söz

Seninki - 2. zamir Yanındakinin karısından veya kocasından söz ederken kullanılan söz

3. zamir Yakın çevrede olan bir kimseden söz ederken kullanılan bir söz

Siz - 1. zamir Çokluk ikinci kişi zamiri

Sizinki - 2. zamir Yakın çevrede olan bir kimseden söz ederken kullanılan bir söz

Şu - 2. zamir Biraz uzakta olan bir varlığı veya biraz önce anılan bir şeyi işaret yolu ile belirtmek için kullanılan söz, şurası

"Bunu istemem, şunu isterim."

Şu bu - zamir Birtakım kimseler ve nesneler

"Plastik deyince bu devirde birtakım naylon eşya, şu bu geliyor hatıra." - N. F. Kısakürek

Şuncası-zamir Şu kadarı

"Şuncasını söyleyeyim, ben şiirin şarkılaştırılarak okunmasını sevmem." - M. C. Anday

Şunlar - zamir Şu zamirinin çokluk biçimi

Topu - zamir Hepsi

"Sarf edilen gayretlerin topu, halkımıza turizmin önemini, yararlarını belletmeye yönelmiş görünüyor." - N. Cumalı

Yedi mahalle - 1. zamir Herkes

"Yedi mahalle duydu."

Yediden yetmişe - zamir Herkes

"O sabah yediden yetmişe bütün obayı aldılar götürdüler kasabaya, bastılar içeri." - Y. Kemal

Yekdiğeri - zamir Bir diğeri, ötekisi

"Yavaş yavaş başlarını kaldırıp yekdiğerinin yüzüne baktılar, ikisinin de gözleri parıldadı." - A. H. Müftüoğlu

Zekilik - zamir Zeki olma durumu, zeyreklik

\section{SONUC}

Sözlükler, yalnızca kelimelerin anlamlarını içeren eserler değildir. Çok amaçlı olarak hazırlanmış sözlüklerde, anlamların yanında dil bilgisi çalışmalarına yardımcı olabilecek bilgiler de bulunur. Bir kelimenin sözlükte sıralanan anlamlarına bağlı olarak sıfat $\mathrm{m}$, ad $\mathrm{m}$, edat $\mathrm{m}$, ünlem mi, zarf $\mathrm{m}$, bağlaç mı olduğu kısaltmalarla verilir (Zülfikar, 2008: 224). Üstelik sözlüklerdeki dil bilgisel bilgi sadece kelimenin türü ile sınırlı değildir. Örneğin Türkçe Sözlük, fiillerin hangi durum ekiyle kullanıldığını gösterir. Kullanıcılar sözlüğe baktıklarında unutmak fiilinin - $-(-i,-u$, - $u$ ) belirtme durumu ekiyle (Her şey-i unuttum), bakmak fiilinin -a (e) yönelme durumu ekiyle (Bakma-y-a klyamam), oturmak fiilinin bulunma durumu ekiyle (Bahçeli-de oturuyor), ayırmak fiilinin -dan (-den, -tan, -ten) ayrılma durumu ekiyle (Beni yanından ayırmiyor) kullanıldığını (Zülfikar, 2008: 225) görürler. Bunların yanında modern sözlükler, "yazım, telaffuz, vurgu, heceleme, sözcük türü kategorisi, biçimsel bilgi, köken bilgisi, kelime anlamı/sözlüksel anlam, cümle yapıları, pragmatik veya kullanım bilgisi, eşdizimlilik, sınıflama, özel alan ve dil dışı veya ansiklopedik bilgi" içerir (Sterkenburg, 2003: 7). Yani sözlükler, ses bilgisinden yapı bilgisine, söz diziminden anlam bilgisine kadar pek çok dil bilgisel bilgiyle örülmüş metinlerdir. Kullanıcılar sözlüğe ne için başvururlarsa başvursunlar, doğrudan veya örtük olarak dil bilgisel bilgilerle karşılaşırlar. Bu yüzden sözlük, dil bilgisel bilgilerin öğrenilmesi için bir bağlam görevi üstlenir. Öğrenciler, sözlüğe başvurduğunda okulda öğrendikleri dil bilgisel bilgileri somutlaştıracak örnekler veya açıklamalar bulurlar. Ya da zamirler örneğinde olduğu gibi doğrudan bir dil bilgisel bilgiyi arayabilir ve onu madde başı olarak sözlükte bulabilirler. Bu, öğrencilerin veya diğer kullanıcıların kelimenin dil bilgisel durumu hakkında zihinlerinde bir soru işareti oluştuğunda sözlüklere başvurarak işin doğrusunu rahatlıkla öğrenebileceği anlamına gelir.

Öğrencileri, dil bilgisel bilgi için sözlük kullanmaya iten/zorlayan en önemli şey, sözlüklerin mevcut dil bilgisi kitaplarından çok daha fazla bilgi içermesidir. Öğrenciler dil bilgisi kitaplarında konuların anlatımını bulabilirler. Ancak konuya ait tüm söz varlığını bulamazlar. Kitaplar anlatılanı örnekleyen sınırlı bir söz varlığına sahiptir. Herhangi bir dil bilgisel bilgi türüne ait en geniş örnek sayısı, dilin tüm söz varlığını içeren genel sözlüklerde bulunur. Bunun somut örneği Türkçede bulunan zamirlerdir. Türkçenin dil bilgisi konularını akademik seviyede işleyen 15 kitap incelendiğinde zamirlerle ilgili şu verilerle karşılaşılmıştır. 
Tablo 1: Dil Bilgisi Kitaplarında Bulunan Zamirlerin Sayıs1

\begin{tabular}{|c|l|l|c|}
\hline Sıra & Kitap Adı & Yazarı & $\begin{array}{c}\text { İçerdiği } \\
\text { Sayısı }\end{array}$ \\
\hline 1 & Dilbilgisi & Tahir Gencan & 45 \\
\hline 2 & Ses ve Şekil Bilgisi & $\begin{array}{c}\text { Ahmet Kırkkılıç ve A. Halim } \\
\text { Ulaş }\end{array}$ & 44 \\
\hline 3 & Ses ve Sekil Bilgisi & Hanifi Vural ve Tuycay Böler & 56 \\
\hline 4 & Sözcük Türleri & İbrahim Delice & 36 \\
\hline 5 & Sözcük Türleri & $\begin{array}{c}\text { Neşe Atabay, İbrahim Kutluk } \\
\text { ve Sevgi Özel }\end{array}$ & 46 \\
\hline 6 & Türk Dil Bilgisi & Jean Deny & 31 \\
\hline 7 & Türk Dil Bilgisi & Feyza Hepçilingirler & 38 \\
\hline 8 & Türk Dil Bilgisi & Muharrem Ergin & 43 \\
\hline 9 & Türkçe Dilbilgisi & M. Kaya Bilgegil & 69 \\
\hline 10 & Türkçe Dilbilgisi & Sezai Güneş & 58 \\
\hline 11 & Türçce Dilbilgisi & Mehmet Hengirmen & 37 \\
\hline 12 & Türkçe Dilbilgisi & Tufan Demir & 41 \\
\hline 13 & Türçcenin Dil Bilgisi & Günay Karaağaç & 37 \\
\hline 14 & Türkçenin Grameri & Tahsin Banguoğlu & 45 \\
\hline 15 & Türkiye Türkçesi Grameri & Zeynep Korkmaz & 40 \\
\hline
\end{tabular}

Tablo 1'de görüldüğü gibi Türkçenin dil bilgisi kitapları dilin kurallarını açıklarken birbirinden farklı sayıda zamir örnekleri sunmaktadır. Oysa Türkçenin zamirleri bunlarla sınırlı değildir. Yukarıda da listesi verilen bu kelimelerin sayısı kitaplarda bulunanlardan çok daha fazladır. Bu durumda okuma, yazma veya konuşma esnasında kullanacağı uygun bir zamir arayan kişi dil bilgisi kitaplarına baktığında ihtiyacını gideremeyebilir. Onun sorunun çözümü Türkçe Sözlük gibi söz varlığı geniş kaynaklardır. Nitekim yapılan pek çok araştırmaya (Barın and Gür, 2015; Hamdi, 2014; Vahdany et. al, 2014 vb.) göre de kullanıcılar, hatırı sayılır oranda sözlüklerde dil bilgisel bilgi aramaktadır. Bu yüzden sözlüklerde dil bilgisel bilgilerin nasıl düzenlendiği, nerede ve nasıl bulunduğu öğrencilere ve diğer kullanıcılara gösterilmeli ve onlar sözlük kullanmaya teşvik edilmelidir. Zira dil bilgisi, "daha kusursuz düşünmemize yardımcı olur. Doğru konuşmamızda ve yazmamızda etkili olur. Bu yönüyle dilbilgisi herkesi, hepimizi çok yakından ilgilendiriyor. Çünkü dilimizi doğru ve düzgün kullanma konusunda sık sık yanlışlıklarla karşılaşıyoruz. İşte, sesbilgisi, biçimbilgisi, sözdizimi gibi konu alanlarından oluşan dilbilgisi, dilimizin kullanımı açısından büyük önem taşımaktadır. Bu durumda bize düşen görev ve sorumluluk, hem Türkçenin dilbilgisini çok iyi bilmek, hem de onu çok iyi öğretmektir" (Kavcar vd., 2016: 104). Bu yüzden herkes, kitaplarda bulunan veya sınıfta anlatılan dil bilgisel bilgilerle yetinmemeli, sözlüklere başvurarak çok daha fazlasını öğrenmelidir. 


\section{KAYNAKÇA}

Abecassis, M. (2007). Is Lexicography Making Progress? On Dictionary Use and Language Learners' Needs. Lexikos $17,247-258$.

Akalın, Ş. H. (2010).Sözlüğün Tarihi. Türk Dili ve Edebiyat Dergisi, 699, 268-279.

Aksan, D. (1996). Türkçenin Sözvarlı̆̆ı. Ankara: Engin Yayınevi.

Atabay, N., Kutluk, İ. and Özel, S. (1983). Sözcük Türleri. Ankara: Türk Dil Kurumu Yayınları.

Banguoğlu, T. (2007). Türkçenin Grameri. Ankara: Türk Dil Kurumu Yayınları.

Barın, M., Gür, C. (2015). Dictionary Culture Among Students of English: A Case Study. Atatürk Üniversitesi Sosyal Bilimler Enstitüsü Dergisi, 19 (1), 145-162.

Baskın, S. (2014). Türkiye ve Dünyada Sözlük Bilimi: Tanımı, Kapsamı ve Diğer Bilimlerle İlişkisi. International Journal of Language Academy, 2 (4), 445-457.

Baxter, J. (1980). The Dictionary and Vocabulary Behavior: A Single Word or a Handful?. TESOL Quarterly, 14, (3), 325-336

Bejoint, H. (2000). Modern Lexicography. New York: Oxford University Press.

Bergenholtz, H. (2012). What is a dictionary?. Lexikos, 22, 20-30.

Bergenholtz, H. ve Tarp, S. (1995). Manual of Specialized Lexicography: The Preparation of Specialized Dictionaries. Amsterdam, Philadelphia: Benjamins.

Bilgegil, M. K. (2009). Türkçe Dilbilgisi. Erzurum: Salkımsöğüt Yayınları.

Carstens, A. (1995). Language Teaching and Dictionary Use: An Overview. Lexikos, 5, 105-116.

Dakum, W. (2001). Should They Look It Up? The role of dictionaries in language learning, REACT, 20 (1), 27-33.

Dash, N. S. (2007). The Art of Lexicography (Edt. Muhvic, V. and Socanac, D.). Encylopedia of Life Support Systems, 224 - 276. Oxford: EoLSS Publishers.

Delice, H., İ. (2012). Sözcük Türleri. Sivas: Asitan Kitap.

Demir, T. (2006). Türkçe Dilbilgisi. Ankara: Kurmay Kitabevi.

Deny, J. (2012). Türk Dil Bilgisi (çev. Ali Ulvi Elöve). İstanbul: Kabalcı Yayınevi.

Dursunoğlu, H. (2017). Türkiye Türkçesi Ses Bilgisi, Ankara: Pegem Akademi Yayınları.

Eminoğlu, D. (2010). Türk Dilinin Sözlükleri ve Sözlükçülük Kaynakçası. Sivas: Asistan Yayıncılık.

Ergin, M. (2005).Türk Dil Bilgisi. İstanbul: Bayrak Basım Yayım Tanıtım.

Gencan, T., N. (1982). Dilbilgisi. Ankara: Türk Dil Kurumu Yayınları.

Güneş, F. (2007). Türkçe Öğretimi ve Zihinsel Yapılandırma. Ankara: Nobel Yayın Dağıtım.

Güneş, F. (2013). Yapılandırıcı Yaklaşımla Dil Bilgisi Öğretimi. Eğitimde Kuram ve Uygulama, 9 (3), 171-187.

Güneş, S. (2009). Türk Dili Bilgisi. İzmir: Çağlayan Matbaası.

Hamdi, C. (2014). Drawing the Profile of Students of English as Dictionary Users. Revue Sciences Humaines, 41, 57-75.

Hartmann, R. R. K. and James, G. (2001). Dictionary of Lexicography. London: Routledge.

Hengirmen, M. (1999). Türkçe Dilbilgisi. Ankara: Engin Yayınevi.

Hepçilingirler, F. (2016). Türk Dil Bilgisi Öğretme Kitabı. İstanbul: Everest Yayınları.

Jackson, H. (1985). Grammar in the Dictionary. Dictionaries, Lexicography and Language Learning (Ed. Robert Ilson), 53-59. Oxford and New York: Pergamon Press.

Jackson, H. (2002). Lexicography: An Introduction. London and New York: Taylor \& Francis Routledge

Karaağaç, G. (2012). Türkçenin Dil Bilgisi. Ankara: Akçağ Yayınları.

Karaağaç, G. (2013). Dil Bilimi Terimleri Sözlüğü. Ankara: Türk Dil Kurumu Yayınları.

Kavcar, C., Oğuzkan, F., Hasırcı, S. (2016). Türkçe Öğretimi). Ankara: Anı Yayıncılık.

Kırkkılıç, A. ve Ulaş, A., H. (2003). Ses ve Şekil Bilgisi. Erzurum: Bizim Büro Basımevi.

Kocaman, A. (1998). Dilbilim, Sözlük, Sözlükçülük. Kebikeç, Sayı 6, 111-113.

Komisyon (2011). Türkçe Sözlük. Ankara: Türk Dil Kurumu Yayınları.

Korkmaz, Z. (2003).Türkiye Türkçesi Grameri. Ankara: Türk Dil Kurumu Yayınları.

Landau, I. S. (2001). Dictionaries: The Art and Craft of Lexicography. Cambridge: Cambridge University Press.

Nielsen, S. (1990). Lexicographic Macrostructures. Hermes (Journal of Language and Communication Studies), 4: 4966.

Özmen, M. (2016). Türkçenin Sözdizimi. Adana: Karahan Kitabevi.

Sterkenburg, P. van (2003). The Dictionary: Definition and History. A Practical Guide to Lexicography (Ed. Piet van Sterkenburg). Amsterdam/Philadelphia: John Benjamins Publishing Company.

Svensén, B. (2009). A Handbook of Lexicography: The Theory and Practice of Dictionary Making. Cambridge: Cambridge University Press.

Vahdany, F., Abdollahzadeh, M., Gholami, S. ve Ghanipoor M. (2014). A Study of the Relationship between Type of Dictionary Used and Lexical Proficiency in Writings of Iranian EFL Students. Advances in Language and Literary Studies, 5 (6), 31-38.

Vural H. ve Böler, T. (2012). Ses ve Şekil Bilgisi. İstanbul: Kesit Yayınları.

Zülfikar, H. (2008). Dünden Bugüne Türkçe. Türk Dili, 681, 224-229. 